\title{
The Effectiveness of Augmented Reality in Learning Vector to Improve Students' Spatial and Problem-Solving Skills
}

\author{
https://doi.org/10.3991/ijim.v15i05.19037 \\ Muhamad Ikhsan Sahal Guntur ${ }^{(\varpi)}$, Wahyu Setyaningrum \\ Yogyakarta State University, Yogyakarta, Indonesia \\ ikhsan.guntur@gmail.com
}

\begin{abstract}
The researchers implemented the quasi-experimental method of research. This research was conducted at SMAN 1 Ngemplak, Indonesia. The research was conducted from March to April 2020. In this study, the samples consisted of 70 students divided into two classes, namely Class A and Class B. The students in Class A received treatment by using the Augmented Reality Module (ARM). Meanwhile, Class B students were taught conventionally using a conventional module from the government and GeoGebra application. The instruments used in this study were written tests, the first test was in the form of multiple choices and consisted of 25 questions to measure students' spatial skills, and the second test was in the form of essays, consisted of five questions in order to measure students' problem-solving skills. The reliability of the tests had been tested before collecting the data. The data were analyzed using descriptive statistics and inferential statistics (normality test, homogeneity test, paired t-test, and independent t-test). Based on the analyses' results, it can be concluded that Augment-ed Reality Module has a significant effect on students' problem-solving and spatial skills since there is an improvement in students' mean scores in the pretest and post-test results. Besides, it can be concluded that Augmented Reality learning is more effective than conventional learning since the students are usually taught using conventional modules from the government and GeoGebra application.
\end{abstract}

Keywords - Augmented Reality, Spatial Skills, Problem-Solving Skills

\section{Introduction}

Mathematics plays a fundamental role in a child's development and communication skills in future life. Necessary numeracy skills play a role in developing children's learning outcomes in order to be competent adults. A broader acknowledgment can be developed with other works of literature. However, building a robust Mathematical foundation in early childhood is critical for children's future educational success and their economy, health, and career [1]. Children who enter school with strong Mathematics skills tend to have a higher chance of success, starting from kindergarten to the next levels. 
One of the strategies in improving students' Mathematics skills is by utilizing technology in the learning process [2][3]. Technology utilization in the classroom can be applied using smartphones, tablets, and laptops [4] [5]. Previous research revealed that it could improve students' Mathematics skills rather than laptops by utilizing smartphones and tablets [6]. Guntur stated that one of the smartphone features that can improve students' Mathematics skills is Augmented Reality [7].

Augmented Reality (AR) is a technology designed to combine virtual objects into real objects. Thus, the virtual objects blend into the real things in the display [8]. AR has great potential to be developed since it does not involve any sophisticated tool or expensive hardware. AR can be accessed on a tablet or smartphone, and it can be used in each level of education [9][10].

According to $\mathrm{Wu}, \mathrm{AR}$ 's positive effects in improving students' Mathematics skills had been identified in previous research, such as developing students' skills and knowledge, enhancing students' experiences, and enhancing collaboration skills [11]. Using AR in Mathematics learning can improve students' understanding of abstract concepts [12][13]. Besides, Lee stated that Augmented Reality plays a role in enhancing students' understanding, presenting the teacher's material, making the while teaching efficient, and creating a new and interactive atmosphere in the Mathematics learning process [14].

Moreover, several cognitive skills should be possessed by students in learning Mathematics. According to NCTM, one of them is a problem-solving skill [15]. Problembased learning should be implemented in Mathematics learning at school since it is the fundamental core in learning Mathematics [16].

Besides problem-solving skills, the students should possess spatial skills and be accommodated in the learning process. This is in line with Kaufman's previous research, revealing that AR plays a role in improving students' spatial skills [17]. Also, AR plays a role in stimulating students' interest in learning and improving students' understanding of Geometry [18].

According to previous researches, the studies on exploring Augmented Reality in the Mathematics teaching and learning process, especially in improving students' problemsolving skills and spatial skills, are still limited. Therefore, this research was conducted to identify the Augmented Reality Module's effectiveness in improving students' spatial skills and problem-solving skills. This study's results are expected to be a reference in determining alternatives and innovations in learning mathematics to improve students' spatial skills and problem-solving skills.

\section{Literature Review}

This section discusses several important and related topics in previous literature, such as Problem-Solving Skills, Spatial Skills, and Augmented Reality. 


\subsection{Problem-solving skills}

The essential core of learning mathematics is to solve a problem (problem-solving) $[19$, p. 400]. Problem-solving skills should be taught in school to improve students' understanding of other subjects [20]. NCTM categorizes problem-solving skills as the main focus in Mathematics learning in school [21]. According to [22, p. 112], when problem-solving is categorized as the focus in teaching and learning skills, it can be applied using several strategies. These strategies include teaching for solving a problem; delivering the materials related to problem-solving basic concepts, such as knowledge, understanding, and skills that can be applied in solving problems; focusing on students' process in solving a problem, and applying problem-solving skill as the strategy that can help students in solving any problems [23][24].

As stated by [15], problem-solving skills are categorized as the essential core competencies in the mathematics learning process. Problem-solving skills can also be considered as a process in seeking the combination of several rules that can be applied to solve any situation [25]. Hence, in order to comprehend Mathematics, problem-solving skills should be taught. [19] The curriculum, tasks, or activities related to problemsolving should be developed in the teaching and learning process, and the learning outcome will have resulted from the problem-solving process. Problem-solving skills are the main components in the Mathematics curriculum and Mathematics necessary skills [26]. Hence, based on previous literature, it can be concluded that problem-solving is the main objective in learning Mathematics, and it should be taught in school to improve students' mathematics skills.

\subsection{Spatial skills}

Linn \& Petersen [27] stated that spatial skills refer to someone's skills in simplifying, modifying, producing, and memorizing non-linguistics symbols. Meanwhile, Van de Walle [19] stated that spatial skill could be defined as an intuition about shapes and the relationships among figures. Besides, Mulligan said that spatial skills refer to someone's skill to recognize and manipulate (in thought) the spatial characteristics of an object and the spatial correlation between objects [28]. Spatial skills are the skills of solving spatial problems by using the perception of two and three-dimensional shapes and the understanding of the perceived information and relations [29]. Sarama \& Clements stated that there are five components in spatial skills, such as Spatial Perception, Spatial Visualization, Mental Rotation, Spatial Relation, and Spatial Orientation [30]

\section{$3 \quad$ Method}

The researchers implemented the quasi-experimental method of research using a nonequivalent pretest-posttest design. This study's independent variable was the Augmented Reality Module, and the dependent variables were students' spatial skills and problem-solving skills. 


\subsection{Samples of the study}

This research was conducted in SMAN 1 Ngemplak, Indonesia. This research was conducted from March to April 2020. 2 (two) classes were selected by applying random sampling. After that, two classes were selected for receiving the treatments. Students in Class A received treatment by using the Augmented Reality Module.

Meanwhile, Class B students were taught conventionally using a conventional module from the government and using Geogebra as the learning medium. The teacher used the 3D GeoGebra application since it could be compared with the Augmented Reality Module. The samples consisted of 70 students, while each class consisted of 35 students.

\subsection{The steps of the research}

The steps conducted in this research were: compiling the research instruments (Lesson Plan, Augmented Reality Module, Pretest, and Posttest for each variable, and scoring rubrics for each variable); conducting validity test for the instruments by involving two expert judgments, conducting reliability test for the instruments, conducting preliminary studies and asking for stakeholders' permission in the school, conducting pretest, conducting research, conducting post-test, analyzing data, and drawing conclusions.

\subsection{Research instrument}

Several tests were conducted to collect data on students' problem-solving and spatial skills before receiving the treatment. The test on measuring students' problem-solving skills consisted of 5 questions in the form of essays, and the test on measuring students' spatial skills consisted of 25 questions in the form of multiple choices. The reliability of the test has been tested by using Cronbach Alpha. The result of the reliability test is shown in Table 1.

Table 1. Reliability test

\begin{tabular}{|c|c|c|c|}
\hline \multicolumn{2}{|c|}{ Spacial Skill Test } & \multicolumn{2}{c|}{ Problem Solving Skill Test } \\
\hline Cronbach's Alpha & N of Items & Cronbach's Alpha & N of Items \\
\hline $\mathbf{0 . 9 2 1}$ & 25 & 0.628 & 5 \\
\hline
\end{tabular}

Based on Table 1, Cronbach's Alpha value was higher than 0.6. Hence, the test is categorized as reliable [31]. The test's validity had also been tested by expert judgments, such as two Mathematics lecturers. The result of the validity test indicated that the instrument was categorized as strongly valid. The three experts also validated the module used in the experimental class, and the AR module was feasible to be used. Meanwhile, students in the control class were taught using the government's conventional module, and the validity test was not needed. Since the technology used in the control class is the 3D GeoGebra application, it has been suitable to be compared with the other class to identify each medium's effectiveness. 


\subsection{The technique of analyzing data}

The data were analyzed using descriptive statistics and inferential statistics. The data descriptions are arranged by describing the real data, such as calculating the mean score, the highest score, the lowest score, and standard deviation of the data obtained before and after receiving the treatment.

This study's inferential statistical analysis was a t-test, which consisted of 3 tests that aimed to test 3 different hypotheses. The first is a paired t-test to determine the Augmented Reality module's effectiveness in improving students' spatial skills and problem-solving skills, evaluated from pre-test and post-test results. Then, for the second time, a paired t-test was used to find the effectiveness of conventional learning methods in improving students' spatial skills and problem-solving skills, evaluated from the pretest and post-test results in the control class. Third, an independent t-test was used to identify any difference in students' mean scores based on the post-test results to measure students' spatial skills and problem-solving skills in each class.

The decision-making and conclusion-drawing were at the significance level of $\left(\frac{0.05}{2}=0.025\right)$, while the decision rule is if the significance value is more significant than 0.025 , it meets the normality assumption. Meanwhile, if there is any difference in the mean score, it should be identified whether it is negative or positive to identify which class shows a better result. Univariate normality analysis was conducted by using the Shapiro-Wilk test. The decision-making and conclusion-drawing were at the significance level of 0.05 , while the decision rule is if the significance value is more significant than 0,05 , then it is met the normality assumption. In order to identify the homogeneity of the variants, Levene-Test was used. The decision-making and conclusiondrawing on the hypothesis test were at the significance level of 0,5 . The decision rule is if the significance value is more significant than 0.05 ., then it is met the matrix variance of covariance assumption and the homogeneity of the variance.

\section{$4 \quad$ Result and Discussion}

In learning Vector using Augmented Reality Module, the activities were conducted based on the lesson plan. The data were collected by conducting pre-test and post-test to identify students' problem-solving skills and spatial skills. The results of the tests were analyzed and presented as descriptions before conducting an inferential statistics test.

\subsection{Result}

The research results are processed and presented in descriptions to give an initial view for the researchers. The descriptions of the data of students' problem-solving skills in the three classes are shown in table 2. 
Table 2. Problem Solving Skill Data Description

\begin{tabular}{|l|c|c|c|c|c|}
\hline & N & Min & Max & Mean & Std. Dev \\
\hline PRE_PSS_ARM & 35 & 40 & 85 & 63.9714 & 12.084 \\
\hline POST_PSS_ARM & 35 & 66 & 100 & 85.9714 & 9.0861 \\
\hline PRE_PSS_MC & 35 & 50 & 85 & 66.0857 & 10.268 \\
\hline POST_PSS_MC & 35 & 68 & 90 & 79.0571 & 6.3660 \\
\hline Valid N (listwise) & 35 & & & & \\
\hline
\end{tabular}

In the description, PRE_PSS_ARM is students' score of problem-solving skills pretest in the class taught using Augmented Reality Module. POST_PSS_ARM is students' score of problem-solving skills post-test in the class taught using the Augmented Reality module. PRE_PSS_MC is students' score of problem-solving skills pre-test in the control class, and PRE_PSS_MC is students' score of problem-solving skills in the control class.

Based on Table 2, it can be identified that students' mean score on problem-solving skills in ARM and Control class before receiving treatment was below the average value (75), since students' mean score of pre-test in ARM class was 63.97, and in the Control class was 66.08. However, after receiving treatment, students' mean score of post-test in ARM class is 85.97, or greater than 75. Meanwhile, students' mean score of posttest in Control class is 79.05. As a result, it indicates an improvement based on the pretest and post-test results on students' problem-solving skills variable.

The descriptions of students' spatial skills in the Mathematics learning process in three classes are shown in Table 3.

Table 3. Description of spatial skill data

\begin{tabular}{|l|c|c|c|c|c|}
\hline & N & Minimum & Maximum & Mean & Std. Dev \\
\hline PRE_SS_ARM & 35 & 54 & 84 & 71.82 & 8.7194 \\
\hline POST_SS_ARM & 35 & 66 & 100 & 84.62 & 10.020 \\
\hline PRE_SS_MC & 35 & 50 & 88 & 67.31 & 11.190 \\
\hline POST_SS_MC & 35 & 55 & 100 & 75.6 & 13.737 \\
\hline Valid N & 35 & & & & \\
\hline
\end{tabular}

Based on Table 3, the results of the Spatial skills test indicate that students' mean score in ARM class and Control class before receiving the treatment was below the average score (75), while students' mean score in ARM class was 71.82, and students' mean score in Control class was 67.31. Meanwhile, after receiving treatment, their mean score is increased above 75, while students' mean score in ARM class was 84.62, and students' mean score in the Control class was 75.6. As a result, the result of descriptive statistics indicated an improvement in each variable. However, to ensure the conclusion of the hypothesis, the inferential statistical test was conducted. The first step was conducting a normality test and continued testing the data's homogeneity using an independent t-test.

Furthermore, the normality tests were conducted for four classes using the ShapiroWilk test. The normality tests were conducted for two classes and each variable, both in pre-test and post-test. The results of the normality tests are shown in table 4. 
Table 4. Normality test with Shapiro-Wilk test

\begin{tabular}{|l|c|c|c|}
\hline & Statistic & df & significance. \\
\hline POST_SS_ARM & .943 & 35 & .068 \\
\hline POST_SS_MC & .939 & 35 & .053 \\
\hline PRE_SS_ARM & .939 & 35 & .052 \\
\hline PRE_PSS_ARM & .963 & 35 & .275 \\
\hline POST_PSS_ARM & .939 & 35 & .052 \\
\hline PRE_SS_MC & .947 & 35 & .089 \\
\hline PRE_PSS_MC & .945 & 35 & .078 \\
\hline POST_PSS_MC & .948 & 35 & .099 \\
\hline
\end{tabular}

Table 4 indicated that the whole data's significance value (in all classes) is greater than 0.05 . Hence, it is met with the normality assumption. Furthermore, the homogeneity test for problem-solving skills post-test in ARM class and control class and homogeneity test for spatial skills post-test in ARM class and control class were conducted using independent t-test. The results of the homogeneity test in each class are shown in Table 5 .

Table 5. Test of homogeneity of variances

\begin{tabular}{|l|c|c|c|c|}
\hline & Levene Statistic & Df1 & Df2 & Sig. \\
\hline PSS & 0.074 & 1 & 68 & 0.786 \\
\hline SS & 3.199 & 1 & 68 & 0.078 \\
\hline
\end{tabular}

In the description, SS is Spatial Skills, and PSS is Problem-solving Skills. Table 5 indicates that from the result of the Levene-test, the significance value is more significant than 0.05 . Hence, it is met the homogeneity assumption of the variance, both in ARM class and Control class.

The results of ARM's effectiveness in improving students' problem-solving skills and spatial skills are shown in Table 6.

Table 6. Paired samples t-test in ARM class

\begin{tabular}{|l|c|c|c|c|c|}
\hline & Mean & Std. Dev & t & df & sig \\
\hline PRE_SS_ARM - POST_SS_ARM & -12.8 & 14.83597 & -5.104 & 34 & .000 \\
\hline PRE_PSS_MC - POST_PSS_ARM & -22.000 & 15.60354 & -8.341 & 34 & .000 \\
\hline
\end{tabular}

Based on table 6, the sig (2 tailed) p-values of PRE_SS_ARM - POST_SS_ARM is lower than 0.025 . Hence, $\mathrm{H} 0$ is accepted. In other words, the hypothesis "there is any significant difference between students' mean score in spatial skills pre-test and posttest in the class that is taught using ARM" is accepted. Furthermore, based on the negative mean difference value, $\mu_{2}>\mu_{1}$, while $\mu_{2}$ is the post-test, and $\mu_{1}$ is the pre-test. Hence, it can be concluded that there is an improvement in students' spatial skills taught using the Augmented Reality Module.

Besides, based on table 6, the sig (2 tailed) p-values of PRE_PSS_ARM POST_PSS_ARM is lower than 0.05 . Hence, H0 is accepted. It can be concluded that the hypothesis "there is any significant difference between students' mean score in 
problem-solving skills pre-test and post-test in the class that is taught using ARM" is accepted. Furthermore, based on the negative mean difference value, $\mu_{2}>\mu_{1}$, while $\mu_{2}$ is the post-test, and $\mu_{1}$ is the pre-test. Hence, it can be concluded that there is an improvement in students' problem-solving skills taught using the Augmented Reality Module.

Table 7. Paired samples t-test in the control class

\begin{tabular}{|l|c|c|c|c|c|}
\hline & Mean & Std. Dev & t & Df & sig \\
\hline PRE_SS_MC - POST_SS_MC & -8.2857 & 18.47028 & -2.654 & 34 & 0.012 \\
\hline PRE_PSS_MC - POST_PSS_MC & -12.971 & 12.68275 & -6.051 & 34 & 0.000 \\
\hline
\end{tabular}

Based on table 7, the sig (2 tailed) p-values of PRE_PSS_MC - POST_PSS_MC are lower than 0.025 . Hence, $\mathrm{H} 0$ is accepted. It can be concluded that the hypothesis "there is any significant difference between students' mean score in spatial skills pre-test and post-test in the control class" is accepted. Furthermore, based on the negative mean difference value, $\mu_{2}>\mu_{1}$, while $\mu_{2}$ is the post-test and $\mu_{1}$ is the pre-test. Hence, it can be concluded that there is an improvement in students' spatial skills in the control class.

In addition, based on table 7, the sig (2 tailed) p-values of PRE_PSS_MC POST_PSS_MC are lower than 0.025 . Hence, H0 is accepted. It can be concluded that the hypothesis "there is any significant difference between students' mean score in problem-solving skills pre-test and post-test in the control class" is accepted. Furthermore, based on the negative mean difference value, $\mu_{2}>\mu_{1}$, while $\mu_{2}$ is the post-test, and $\mu_{1}$ is the pre-test. Hence, it can be concluded that there is an improvement in students' problem-solving skills in the control class.

Since it has been known that there is a difference in students' mean scores based on pre-test and post-test results, an independent t-test was conducted in order to identify which class has better learning outcomes, assessed from the post-test results on problem-solving skills and spatial skills. The results of the independent t-test are shown in Table 8.

Table 8. Independent T-test between ARM post-test and MC post-test

\begin{tabular}{|l|c|c|c|c|c|}
\hline & Mean & Std. Deviation & t & df & sig \\
\hline Spatial Skill & 9.0285 & 2.87419 & 3.141 & 68 & .002 \\
\hline Problem-solving skills & 6.9142 & 1.87528 & 3.687 & 68 & .000 \\
\hline
\end{tabular}

Based on Table 8, the sig ( 2 tailed) p-value on spatial skills is lower than 0.025 . Hence, H0 is accepted. In other words, it can be concluded that the hypothesis "there is any significant difference between students' mean score in spatial skills post-test result in ARM class and MC class" is accepted. Furthermore, based on the positive mean difference value, $\mu_{1}$ is better than $\mu_{2}$, while $\mu_{2}$ is the control class post-test, and $\mu_{1}$ is the ARM class post-test.

Based on table 8 , the sig (2 tailed) p-value on problem-solving skills is lower than 0.025 . Hence, $\mathrm{H} 0$ is accepted. In other words, it can be concluded that the hypothesis "there is any significant difference between students' mean score in problem-solving skills post-test result in ARM class and MC class" is accepted. Furthermore, based on 
the positive mean difference value, $\mu_{1}$ is better than $\mu_{2}$, while $\mu_{2}$ is the post-test for the control class, and $\mu_{1}$ is the post-test for the ARM class.

\subsection{Discussion}

Based on Table 6 and Table 7, it can be concluded that there is no improvement in both classes, and both on the spatial skills and problem-solving skills. The hypothesis test result reveals that conventional approaches effectively improve students' problemsolving skills and spatial skills.

In identifying students' problem-solving skills in conventional classes, it can be concluded that the improvement is due to the use of a module published by the government since the competencies related to problem-solving skills contained in Indonesia's curriculum. Meanwhile, Augmented Reality Module has been designed for improving students' problem-solving skills. The differences between both modules are in the indicators of problem-solving skills, such as understanding the problem, making plans, and conducting evaluation in each previous stage [32]. Besides, in the learning process, the AR module plays a role in stimulating and attracting students' interest in solving problems since the AR module's appearance is more exciting and challenging (Wasko, 2013). Figure 1 indicates the comparison between the Augmented Reality Module (MAR) test and the module used by students of the control class (MC).

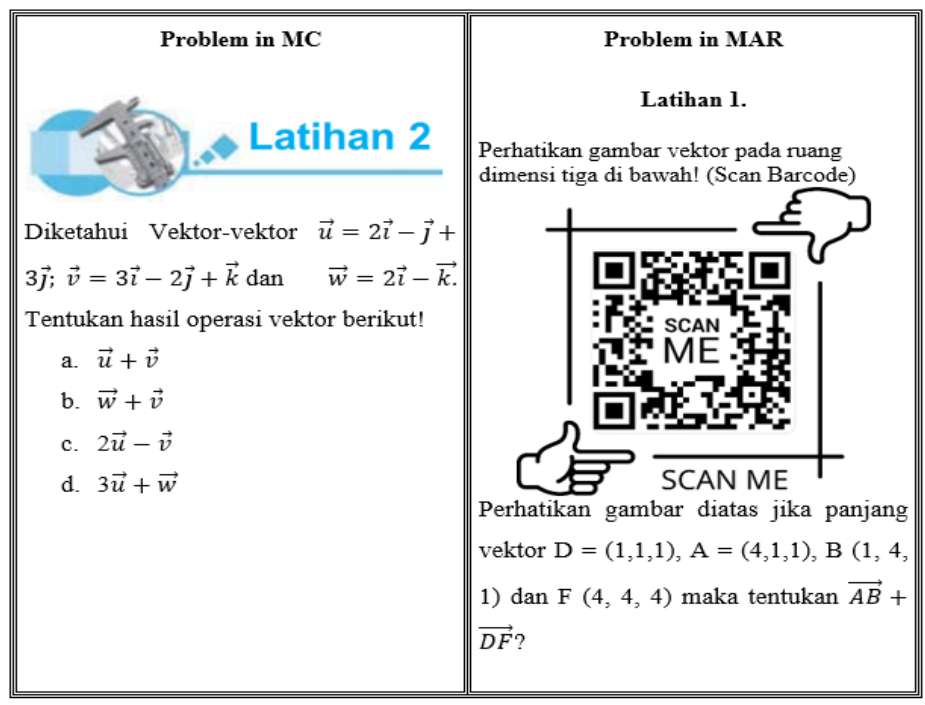

Fig. 1. The Comparison of the Test

Meanwhile, in identifying students' spatial skills improvement in the control class, the teacher's strategy in using Geogebra application in the learning process is due to the teacher's strategy. Geogebra application is the latest version, and it presents three dimensions objects that can stimulate students' spatial skills [34]. The difference between these two technologies is: even though the first application (Geogebra) is in the 
three-dimensional form (3D), but the students cannot see the whole objects from various sides, and the student can only play with the object on the computer by using a mouse. Meanwhile, the students can access the Augmented Reality Module directly by using their smartphones, and it seems real. These two applications are free of charge since these applications' development is limited to specific spaces, but the researchers' module is the Augmented Reality Module customized based on the user's requests. A picture is a feature that can only be found in AR, and it distinguishes AR and Geogebra 3D applications.

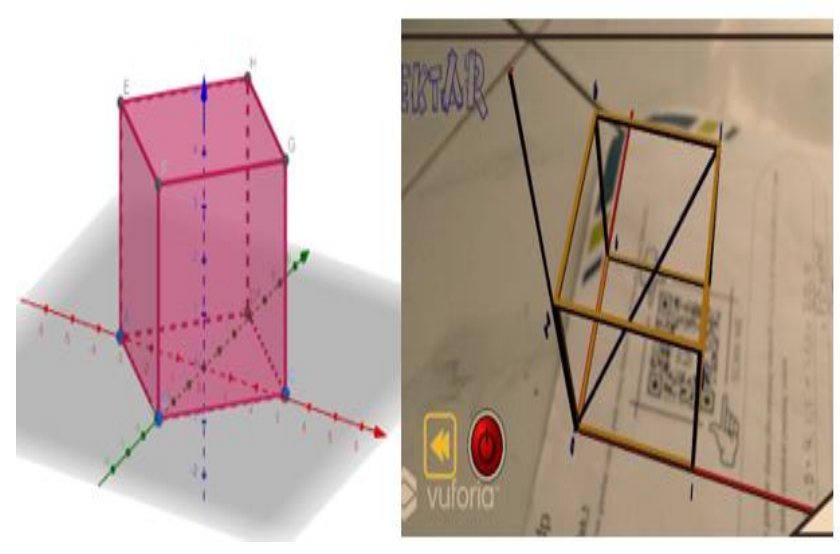

Fig. 2. The differences between $3 \mathrm{D}$ AR and Geogebra.

However, even though there is an improvement in students' problem-solving skills and spatial skills in the control class, based on table 8, the improvement of students who are taught using ARM is immense. This is due to the differences between the Augmented Reality Module and the teacher's conventional module. It is in line with the results of previous studies that ARM can improve students' problem-solving skills [35][36][37][38][39], and ARM is effective in attracting students' interest in answering the test, which consists of several questions related to problem-solving -skills [40]

Based on Table 8, the Augmented Reality Module's effectiveness in improving students' spatial skills is higher than the control class since Vector material is difficult to be explained by using a whiteboard, or it can only be displayed simultaneously using the Augmented Reality Module. Students can see the vector shape in various 3D views, and it has a direct effect on students' spatial skills based on several aspects, such as Spatial Perception, Spatial AR Visualization, Mental Rotation, Spatial Relation, Spatial Orientation, that are provided and developed in Augmented Reality learning [41-49].

There is a correlation between problem-solving and spatial skills since spatial skills play a role in developing problem-solving skills [50]. In line with Guntur's previous research, spatial skills can stimulate students' problem-solving skills since they are correlated with each other [51]. The relationship between Augmented Reality, problemsolving skills, spatial skills, and Augmented Reality improves both of the skills shown in Figure 3. 


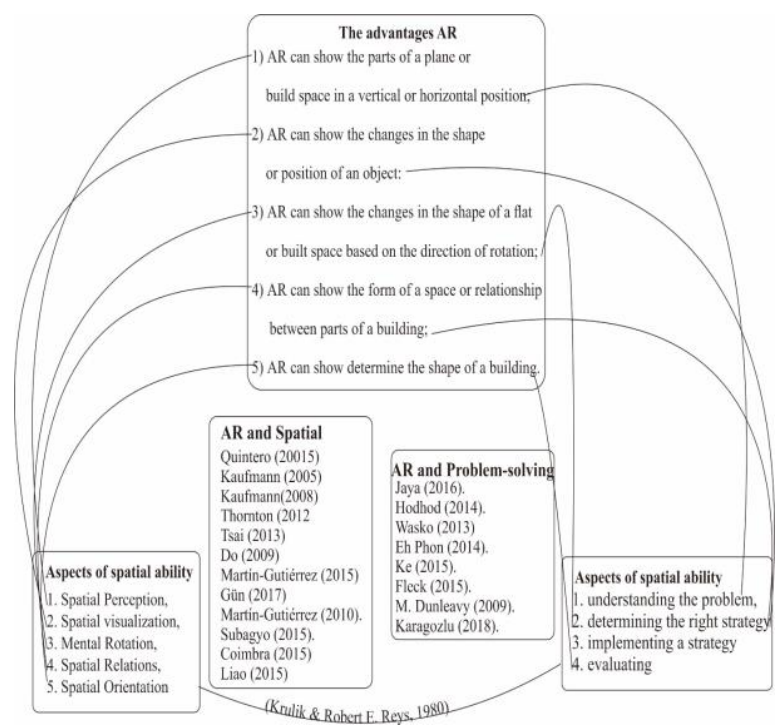

Fig. 3. The relationship between AR, spatial skills, and problem-solving skills

\section{Conclusion}

Based on the results of the analyses, it can be concluded that the use of the Augmented Reality Module is effective in improving problem-solving skills and spatial skills, as proved by the improvement in students' mean score in pre-test and post-test. Besides, besides comparing the post-test scores in each class, it can also be concluded that using the Augmented Reality Module in the learning process is more effective than conventional learning since the students are usually taught using a conventional module from the government and Geogebra application.

This study's results can be a reference for teachers and other researchers to use Augmented Reality Module to improve students' spatial skills and problem-solving skills in learning Mathematics. This study's limitations are that the module's material is limited to Vector material for the tenth-grade students, and the program can only be accessed on Android. For further research, developing other Augmented Reality modules for other materials and using a larger population is suggested.

\section{Acknowledgement}

We would thank DRPM Kemenristekdikti of Indonesia, who has funded this research, thanks to SMAN 1 Ngemplak for the permission given to be done, thanks to Yogyakarta State University. 


\section{$7 \quad$ References}

[1] S. Papadakis, M. Kalogiannakis, and N. Zaranis, "Improving Mathematics Teaching in Kindergarten with Realistic Mathematical Education," Early Childhood Education Journal, vol. 45, no. 3, pp. 369-378, 2017, https://doi.org/10.1007/s10643-015-0768-4

[2] S. Papadakis, M. Kalogiannakis, and N. Zaranis, "The effectiveness of computer and tablet assisted intervention in early childhood students' understanding of numbers. An empirical study conducted in Greece," Education and Information Technologies, vol. 23, no. 5, pp. 1849-1871, 2018, https://doi.org/10.1007/s10643-015-0768-4

[3] H. Hedberg, J. Nouri, P. Hansen, and R. Rahmani, "A Systematic Review of Learning through Mobile Augmented Reality," International Journal of Interactive Mobile Technologies (iJIM), vol. 12, no. 3, pp. 75-85, 2018. https://doi.org/10.3991/ijim.v12i3.8404

[4] Zaranis, N., Kalogiannakis, M., \& Papadakis, "Using mobile devices for teaching realistic mathematics in kindergarten education. Creative Education, 4(07), 1.," SciRes, vol. 4, no. 7, p. 1, 2013, https://doi.org/10.4236/ce.2013.47a1001

[5] Hejab Ma'azer Al Fawareh and S. Jusoh, "The Use and Effects of Smartphones in Higher Education," International Journal of Interactive Mobile Technologies (iJIM), vol. 11, no. 6, pp. 103-111, 2017. https://doi.org/10.3991/ijim.v11i6.7453

[6] S. Papadakis, M. Kalogiannakis, and N. Zaranis, "Comparing Tablets and PCs in teaching Mathematics: An attempt to improve Mathematics Competence in Early Childhood Education," Preschool and Primary Education, vol. 4, no. 2, p. 241, 2016, https://doi.org/10.12681/ ppej.8779

[7] M. I. S. Guntur, W. Setyaningrum, H. Retnawati, and M. Marsigit, "Assessing the Potential of Augmented Reality in Education," in The 11th International Conference on E-Education, E-Business, E-Management and E-Learning (IC4E 2020)--EI \& Scopus, 2020, pp. 93-97, https://doi.org/10.1145/3377571.3377621

[8] R. Azuma, Y. Baillot, R. Behringer, S. Feiner, S. Julier, and B. MacIntyre, "Recent advances in augmented reality," IEEE Computer Graphics and Applications, 2001, https://doi.org/10.1109/38.963459

[9] M. Akçayır and G. Akçayır, "Advantages and challenges associated with augmented reality for education: A systematic review of the literature," Educational Research Review, vol. 20, pp. 1-11, 2017, https://doi.org/10.1016/j.edurev.2016.11.002

[10] P. Menezes, “An Augmented Reality U-Academy Module : From Basic Principles to Connected Subjects," International Journal of Interactive Mobile Technologies (iJIM), vol. 11, no. 5, pp. 105-117, 2017. https://doi.org/10.3991/ijim.v11i5.7074

[11] H. K. Wu, S. W. Y. Lee, H. Y. Chang, and J. C. Liang, "Current status, opportunities and challenges of augmented reality in education," Computers and Education, vol. 62, pp. 4149, 2013, https://doi.org/10.1016/j.compedu.2012.10.024

[12] K. R. Bujak, I. Radu, R. Catrambone, B. MacIntyre, R. Zheng, and G. Golubski, “A psychological perspective on augmented reality in the mathematics classroom," Computers and Education, vol. 68, pp. 536-544, 2013, https://doi.org/10.1016/j.compedu. $\underline{2013.02 .017}$

[13] G. Liestøl, “Augmented Reality Storytelling Narrative Design and Reconstruction of a Historical Event in situ," International Journal of Interactive Mobile Technologies (iJIM), vol. 13, no. 10, pp. 196-209, 2019. https://doi.org/10.3991/ijim.v13i12.11560

[14] K. Lee, "Augmented Reality in Education and Training, 56(2), 13-21. doi," Tech Trends, vol. 56, no. 2, pp. 13-21, 2012, https://doi.org/10.1007/s11528-012-0559-3.

[15] NCTM, The principles, and standards for school mathematics. Reston: National Council of Teachers of Mathematics., 2000. 
[16] G. Butterworth, J., \& Thwaites, Thinking Skills: Critical Thinking and Problem Solving, Second Edi. Cambridge.: Cambridge University Press, 2013.

[17] H. Kaufmann, K. Steinbügl, A. Dünser, and J. Glück, "Improving Spatial Abilities by Geometry Education in Augmented Reality - Application and Evaluation Design," in Proceedings of the Virtual Reality International Conference (VRIC), 2005, pp. 25-34. https://doi.org/10.1145/1152760.1152776

[18] Coimbra, "Augmented reality: an enhancer for higher education students in maths learning?," in 6th International Conference on Software Development and Technologies for EnhancingAccessibility and Fighting Infoexclusion, 2015, pp. 332 - 339, doi: 10.1016/j.procs.2015.09.277.

[19] J. A. Van de Walle, K. S. Karp, and J. M. Bay-Williams, Elementary and middle school mathematics teaching developmentally, 7th ed. Boston, New York San Francisco: Allyn \& Bacon, 2010.

[20] Erkki Pehkonen, Liisa Näveri, and Anu Laine, "On teaching problem-solving in school mathematics On Teaching Problem Solving in School Mathematics," c.e.p.s Journal, vol. 3, no. 4, pp. 9-24, 2013. https://doi.org/10.37626/ga9783959870641.0.25

[21] Jarrett, D., Stepanek, and A. Sutton, "Problem-solving: Getting to the heart of mathematics.," A Math and Science Journal, vol. 1, pp. 1-24, 2000.

[22] R. Killen, Effective teaching strategies: a lesson from research and practice., 7th ed. South Melbourne: Cengage Learning, 2016.

[23] S. E. and M. Swan, "students ' strategies for problem-solving in mathematics : ' Sample Student Work,'" Journal Of The International Society for Design and Development in Education, vol. 2, no. 7, pp. 1-31, 2014.

[24] E. Ersoy, "Problem-solving and its teaching in mathematics," The Online Journal of New Horizons in Education, vol. 6, no. 2, pp. 79-87, 2016.

[25] M. Wena, Strategi pembelajaran inovatif kontemporer, 6th ed. Jakarta: Bumi Aksara, 2011.

[26] J. Kirkley and R. Foshay, "Principles for Teaching Problem Solving," in Technical Paper, The Roach Organization, inc, 2003.

[27] M. C. Linn and A. C. Petersen, "Emergence and characterization of sex differences in spatial ability," Child Development, vol. 56, no. 6, pp. 1479-1498, 1985, https://doi.org/10. 2307/1130467

[28] J. Mulligan, "Looking within and beyond the geometry curriculum: connecting spatial reasoning to mathematics learning.," ZDM Mathematics Education, vol. 47, pp. 511-517, 2015, https://doi.org/10.1007/s11858-015-0696-1

[29] A. Bosnyak and R. N. Kondor, "The spatial geometry and spatial geometrical knowledge of university students, majored in mathematics," Acta Dicdactica Universitatis Comeniunde, vol. 8, no. 1, pp. 1-25, 2008.

[30] J. Sarama and D. H. Clements, Early childhood mathematics education research (Learning trajectory for young children). New York, NY: Routledge Taylor and Francis Group., 2009.

[31] R. L. Ebel and D. A. Frisbie, Essentials of Educational Measurement, 5th Ed. USA: PrenticeHall, Inc, 1991.

[32] Polya, How to Solve It: A new aspect of mathematical methods. USA: Princeton University Press, 2004.

[33] C. Wasko, "What Teachers Need to Know About Augmented Reality Enhanced Learning Environments," TechTrends, vol. 57, no. 4, pp. 17-21, 2013, doi: 10.1007/s11528-0130672-y. https://doi.org/10.1007/s11528-013-0672-y

[34] R. Vágová and M. Kmetová, "Geogebra, a Tool to Improve Students ' Visual Imaging," ACTA Didactica Napocensia, vol. 12, no. 2, pp. 225-237, 2019, https://doi.org/10. 24193/adn.12.2.18 
[35] D. N. Eh Phon, M. B. Ali, and N. D. A. Halim, "Collaborative augmented reality in education: A review," Proceedings - 2014 International Conference on Teaching and Learning in Computing and Engineering, LATTICE 2014, pp. 78-83, 2014, https://doi.org/10.1109/ latice. 2014.23

[36] F. Ke and Y. C. Hsu, "Mobile augmented-reality artifact creation as a component of mobile computer-supported collaborative learning," Internet and Higher Education, vol. 26, pp. $33-$ 41, 2015, https://doi.org/10.1016/j.iheduc.2015.04.003

[37] S. Fleck, M. Hachet, and J. M. Christian Bastien, "Marker-based Augmented Reality: Instructional-design to improve children interactions with astronomical concepts," Proceedings of IDC 2015: The 14th International Conference on Interaction Design and Children, pp. 21-28, 2015, https://doi.org/10.1145/2771839.2771842

[38] M. Dunleavy, C. Dede, and R. Mitchell, "Affordances and limitations of immersive, participatory augmented reality simulations for teaching and learning," Journal of Science Education and Technology, vol. 18, no. 1, pp. 7-22, 2009, https://doi.org/10.1007/s10956-0089119-1

[39] D. Karagozlu, "Determination of the impact of augmented reality application on the success and problem-solving skills of students," Quality and Quantity, vol. 52, no. 5, pp. 2393-2402, 2018, https://doi.org/10.1007/s11135-017-0674-5

[40] R. Hodhod, H. Fleenor, and S. Nabi, “Adaptive Augmented Reality Serious Game to Foster Problem Solving Skills," 2014.

[41] E. T. Gün and B. Atasoy, "The effects of augmented reality on elementary school students' spatial ability and academic achievement," Egitim ve Bilim, vol. 42, no. 191, pp. 31-51, 2017, https://doi.org/10.15390/eb.2017.7140

[42] T. V. Do and J. W. Lee, "A multiple-level 3D-LEGO game in augmented reality for improving spatial ability," Lecture Notes in Computer Science (including subseries Lecture Notes in Artificial Intelligence and Lecture Notes in Bioinformatics), vol. 5613 LNCS, no. PART 4, pp. 296-303, 2009, https://doi.org/10.1007/978-3-642-02583-9_33

[43] Y. T. Liao, C. H. Yu, and C. C. Wu, "Learning geometry with augmented reality to enhance spatial ability," Proceedings - 2015 International Conference on Learning and Teaching in Computing and Engineering, LaTiCE 2015, pp. 221-222, 2015, https://doi.org/10. 1109/latice.2015.40.

[44] K.-H. C. C.-C. Tsai, “Affordances of Augmented Reality in Science Learning: Suggestions for Future Research," Journal of Science Education and Technology, vol. 22, no. 4, pp. 449462, 2013 https://doi.org/10.1007/s10956-012-9405-9

[45] H. Kaufmann and B. Meyer, "Simulating physical, educational experiments in augmented reality," ACM SIGGRAPH Asia 2008 Educators Programme, SIGGRAPH Asia'08, 2008, https://doi.org/10.1145/1507713.1507717

[46] E. Quintero, P. Salinas, E. González-Mendívil, and H. Ramírez, “Augmented reality app for calculus: a proposal for the development of spatial visualization," Procedia Computer Science, vol. 75, no. Vare, pp. 301-305, 2015, doi: 10.1016/j.procs.2015.12.251. https://doi.org/10.1016/j.procs.2015.12.251

[47] Papadakis, St. (2020). Robots and Robotics Kits for Early Childhood and First School Age. International Journal of Interactive Mobile Technologies (iJIM), 14 (18), 34-56. https://doi.org/10.3991/ijim.v14i18.16631

[48] Papadakis, S. (2020). Apps to Promote Computational Thinking Concepts and Coding Skills in Children of Preschool and Pre-Primary School Age. In Mobile Learning Applications in Early Childhood Education (pp. 101-121). IGI Global. https://doi.org/10.4018/978-1-79981486-3.ch006 
[49] Kalogiannakis, M., \& Papadakis, S. (2020). The Use of Developmentally Mobile Applications for Preparing Pre-Service Teachers to Promote STEM Activities in Preschool Classrooms. In Mobile Learning Applications in Early Childhood Education (pp. 82-100). IGI Global. https://doi.org/10.4018/978-1-7998-1486-3.ch006

[50] S. Krulik and Robert E. Reys, Problem Mathematics. Virginia.: NCTM, 1980.

[51] [51] M. I. S. Guntur, W. Setyaningrum, H. Retnawati, and M. Marsigit, "Can augmented reality improve a problem-solving and spatial skill ?," in International Seminar on Innovation in Mathematics and Mathematics Education, 2020, p. 1581, https://doi.org/10. $\underline{1088 / 1742-6596 / 1581 / 1 / 012063}$

\section{Authors}

Muhamad Ikhsan Sahal Guntur (Scopus ID: 57218398738) is a Master's Mathematics Education student at Yogyakarta State University (ikhsan.guntur@gmail.com).

Wahyu Setianingrum (Scopus ID: 57195479725) is a lecturer at the Faculty of Mathematics Education at Yogyakarta State University. She has concerns about using technology in education. She is an editorial at mathematics education research journal Indonesia (JRPM) and Journal Universitas Mercu Buana Yogyakarta.

Article submitted 2020-10-03. Resubmitted 2020-12-24. Final acceptance 2020-12-24. Final version published as submitted by the authors. 